\title{
Reciprocal modulation of tyrosine hydroxylasea activity in rat carotid body
}

\author{
CONSTANCIO GONZALEZ, YAN KWOK, JAMES W. GIBB and SALVATORE J. FIDONE*
}

Departments of Physiology and Biochemical Pharmacology and Toxicology, University of Utah, Salt Lake City, Utah (U.S.A.)

(Accepted May 5th, 1979)

The carotid body is an arterial chemoreceptor organ responsive to blood levels of $\mathrm{pO}_{2}, \mathrm{pCO}_{2}$ and $\mathrm{pH}^{13}$. The parenchymal tissue of the carotid body is composed mainly of two cell types: the glomus or Type I cells, which are disposed together in groups or glomeruli, and the sustentacular or Type II cells, which appear as glial-like elements enclosing the glomeruli in capsular fashion ${ }^{3,4}$. The Type I cells, which have abundant dense-cored vesicles and are known to contain catecholamines ${ }^{1,2,11,15}$, receive a sensory innervation from afferent fibers of the carotid sinus nerve ${ }^{3}$. Recent studies have also shown the presence of reciprocal synapses at these junctions between afferent nerve terminals and Type I cells ${ }^{18}$. In addition, these cells receive an efferent innervation from both preganglionic and postganglionic sympathetic fibers which reach the carotid body from the superior cervical ganglion ${ }^{18}$.

The principal catecholamine in the Type I cells of the rat carotid body is dopamine $(63 \%)$, the remainder being norepinephrine ${ }^{11}$. Although the precise role of catecholamines in the carotid body remains to be elucidated, there is evidence implicating these substances as neurotransmitters or modulators of chemoreceptor activity $5,6,16,17,20,24$. Of particular interest are the recent findings in rat carotid body that hypoxia induces a long-term increase in tyrosine hydroxylase (TH) activity, the rate-limiting enzyme in catecholamine biosynthesis ${ }^{7,9}$. In these experiments, unanesthetized animals were exposed in a chamber for variable times to low $\mathrm{O}_{2}$ atmospheres. When TH activity was assayed $48 \mathrm{~h}$ following the hypoxic episode there was an increase in enzyme activity of $50-80 \%$ above control values (control animals were exposed only to room air in the chamber). This long-term induction of TH could have resulted from either direct action by the hypoxic stimulus upon the Type I cells of the carotid body, or instead it might have arisen reflexy via the nervous innervation to the organ. TH activity in other catecholaminergic systems is known to be subject to neural control $1,14,21,22$, and as described above the Type I cells of the carotid body receive a complex nervous innervation (afferent, efferent and reciprocal synapses). It is thus

\footnotetext{
* To whom correspondence should be addressed at: Department of Physiology, University of Utah College of Medicine, 410 Chipeta Way, Research Park, Salt Lake City, UT 84108, U.S.A.
} 


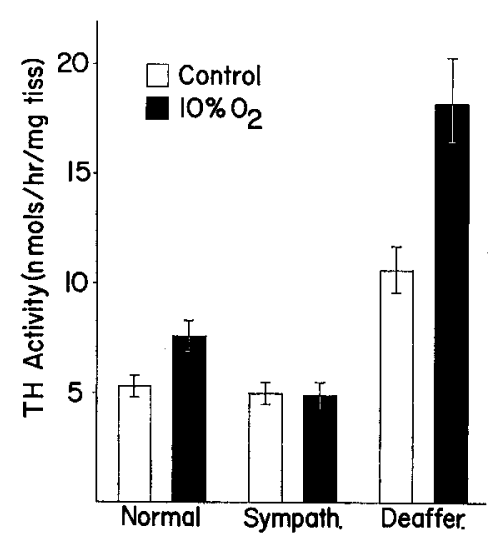

Fig. 1. Effects of hypoxia $\left(10 \% \mathrm{O}_{2}\right)$ on $\mathrm{TH}$ activity in normal, sympathectomized and deafferented rat carotid bodies. Unanesthetized animals were exposed in a chamber for $3 \mathrm{~h}$ to air (clear bars) or $10 \%$ $\mathrm{O}_{2}$ in $\mathrm{N}_{2}$ (black bars), and TH activity assayed $48 \mathrm{~h}$ later. Removal of the superior cervical ganglion (Sympath.) or the carotid sinus nerve (Deaffer.) was performed 12-15 days prior to exposure of the animals in the chamber. Each bar in the figure represents the mean \pm S.E. from 8 rats.

important to an understanding of the role of catecholamines in chemoreception to determine the contributions of the sympathetic innervation and the carotid sinus to the observed induction of TH by hypoxia. In the present study, we have used animals with chronically denervated carotid bodies and we report here that the dual innervation (sympathetic and carotid sinus nerve) to the carotid body exerts a reciprocal control over TH activity in this organ: sympathectomy abolishes TH induction by hypoxia, while section of the carotid sinus nerve enhances both the response to hypoxia and the basal TH levels in the tissue.

Adult Sprague-Dawley rats, weighing between 180-240 g, were housed 3 per cage, at $26^{\circ} \mathrm{C}$ with ad libitum food and water, and a normal dark-light rhythm. In some animals, the superior cervical ganglion or the carotid sinus nerve was removed 12-15 days prior to sacrificing the animals for assay of $\mathrm{TH}$ activity. Unanesthetized rats were exposed for $3 \mathrm{~h}$ either to air (control animals) or to $10 \% \mathrm{O}_{2}$ in $\mathrm{N}_{2}$ (hypoxic animals) in a lucite chamber continuously flushed with the given gas mixture (2-4 rats per exposure; chamber volume, 14 liters; flushing rate, 4 liters/min; gases certified \pm $0.5 \% \mathrm{O}_{2}$ of rated purity, IAP, Portland). Forty-eight hours following exposure, the animals were anesthetized with sodium pentobarbital (i.p.), the trachea cannulated, and the area of the carotid bifurcation exposed with the aid of a dissecting microscope. Carotid bodies were quickly removed from the animals and immediately cleaned of surrounding connective tissue in a dissecting chamber filled with ice-cold physiological saline. The specimens were weighed on a Cahn Electrobalance (sensitivity, $\pm 50 \mathrm{ng}$ ) equipped with a humidified chamber to prevent drying of the tissues. All samples were placed in glass homogenizers containing $0.2 \%$ Triton X-100 and kept on ice until assayed for $\mathrm{TH}$ activity, which was performed according to the method described by Nagatsu et al. ${ }^{19}$. The principle of this method relies on the recovery and measurement 
of tritiated water produced during the hydroxylation of $\mathrm{L}-\left[3,5-{ }^{3} \mathrm{H}\right]$ tyrosine. The assay medium contained the following, expressed as final concentrations in a vol. of $100 \mu 1$ : $1 \mathrm{mM}$ ferrous ammonium sulfate; $2 \mathrm{mM}$ 2-amino-6,7-dimethyl-4 hydroxy-5,6,7,8tetrahydropterine dihydrochloride $\left(\mathrm{DMPH}_{4} ;\right.$ Aldrich); $100 \mathrm{mM}$ 2-mercaptoethanol (Calbiochem); $200 \mathrm{mM}$ sodium acetate buffer, $\mathrm{pH} 6.0 ; 0.1 \mathrm{mM}$ L-tyrosine; $0.4 \mu \mathrm{Ci} \mathrm{L}$ $\left[3,5-{ }^{3} \mathrm{H}\right]$ tyrosine (Amersham); and $50 \mu \mathrm{l}$ of tissue homogenate (of $80 \mu \mathrm{l}$ initial homogenate vol.). The assay reaction was allowed to proceed for $15 \mathrm{~min}$ in a metabolic shaker ( $250 \mathrm{rpm}$; New Brunswick) at $37^{\circ} \mathrm{C}$, and was stopped by addition of $0.1 \mathrm{ml}$ of $10 \%$ TCA. The acidified mixture was passed through a $7 \times 30 \mathrm{~mm}$ purified Dowex 50 $\mathrm{H}^{+}$column (Bio-Rad Laboratories); $1.8 \mathrm{ml}$ of distilled water was used to wash the column, and the combined effluents were collected in scintillation counting vials. Fifteen $\mathrm{ml}$ of scintillation fluid (23 g PPO, 2 liters toluene and 1 liter Triton X-100) were added to each vial prior to counting in a Packard liquid scintillation spectrometer. Blanks were prepared with $50 \mu \mathrm{l}$ of distilled water in place of the tissue homogenate and processed in identical manner. TH activity is expressed as $\mathrm{nmol} / \mathrm{h} / \mathrm{mg}$ tissue, and the values given are means \pm S.E.

As reported previously, TH activity in normally innervated carotid bodies was increased when the enzyme activity was assayed $48 \mathrm{~h}$ following a $1-3 \mathrm{~h}$ hypoxic episode 7,9 . These data are shown in Fig. 1 (normal) and were obtained from rats exposed for $3 \mathrm{~h}$ to $10 \% \mathrm{O}_{2}$ in $\mathrm{N}_{2}$ (black bar) or to air (clear bar). The increase in $\mathrm{TH}$ activity above control values in rats exposed to hypoxia was $43 \%(P<0.01)$. Basal TH levels in chronically sympathectomized carotid bodies were unchanged from control values $(4.97 \pm 0.49$ vs $5.25 \pm 0.46 \mathrm{nmol} / \mathrm{h} / \mathrm{mg}$ tissue, respectively, $P>0.05$ ). However, the increase in TH activity seen in normal animals $48 \mathrm{~h}$ following exposure to $10 \% \mathrm{O}_{2}$ was absent in carotid bodies deprived of their sympathetic innervation (7.57 \pm 0.65 vs $4.88 \pm 0.56 \mathrm{nmol} / \mathrm{h} / \mathrm{mg}$ tissue, respectively, Fig. 1).

In contrast to the results obtained with sympathectomized animals, rat carotid bodies chronically deafferented by removal of the carotid sinus nerve exhibited an increase in both basal TH activity and the per cent rise in TH following hypoxia (Fig. 1, Deaffer.). Basal TH activity more than doubled in the deafferented carotid bodies $(10.64 \pm 1.04 \mathrm{nmol} / \mathrm{h} / \mathrm{mg}$ deafferented carotid body, $P<0.01)$ compared with the normal controls. Forty-eight hours following exposure to hypoxia, rats with deafferented carotid bodies exhibited a $71 \%$ increase in $\mathrm{TH}$ activity above the already elevated basal level (to $18.21 \pm 1.67 \mathrm{nmol} / \mathrm{h} / \mathrm{mg} /$ tissue, $P<0.01$ ). Thus, hypoxia produced a greater increase in $\mathrm{TH}$ activity in deafferented carotid bodies than in normally innervated organs ( $71 \%$ vs $43 \%$, respectively, $P<0.01$ ).

These results demonstrate that the carotid sinus nerve and the sympathetic innervation to the carotid body exert a reciprocal control over long-term changes in TH activity which result from alterations in arterial oxygen tensions. Thus, loss of TH induction by hypoxia follows chronic sympathectomy of the carotid body, and enhancement of the TH response occurs with deafferentation of the organ. Our results differ from those reported by Hanbauer et al. ${ }^{9}$, who found no change in basal TH activity in rat carotid body one week after transection of the carotid sinus nerve. Also, they observed that the induction of TH activity following hypoxia was abolished following 
deafferentation of the carotid body, rather than after sympathectomy, as we report here. However, in their experiments rats were subjected for one hour to severe hypoxia $\left(5 \% \mathrm{O}_{2}\right)$, which may produce a different profile of autonomic adjustment than exposure for $3 \mathrm{~h}$ to moderate hypoxia $\left(10 \% \mathrm{O}_{2}\right)$. Furthermore, Hanbauer and coworkers employed a different method for TH assay than we used, and reported much lower enzyme activities than we found. The apparent discrepancies between our data and those of Hanbauer et al. ${ }^{9}$ have been discussed elsewhere?

Loss of TH induction by hypoxia following sympathectomy of the carotid body suggests that the sympathetic nervous system may play a key role in reflexly mediating TH induction in this organ. This interpretation is consistent with our previous finding that $\mathrm{TH}$ activity in rat superior cervical ganglion, like that in the carotid body, is also increased following hypoxia?. Furthermore, our present data suggest that basal TH levels in the carotid body appear to be tonically regulated, at least in part, by the carotid sinus nerve. This latter phenomenon might occur by means of the reciprocal synaptic organization which exists between afferent nerve terminals and Type I cells ${ }^{18}$. However, a recent study by Vazquez-Nin et al. ${ }^{23}$ shows that chronic deafferentation of the cat carotid body results in sprouting and proliferation of sympathetic nerve terminals on Type I cells. If such were also the case in rat carotid body, the increased TH activity following deafferentation might reside in the newly-formed nerve terminals. However, sympathectomy alone does not significantly reduce carotid body TH (Fig. 1), and the activity of the enzyme doubles following deafferentation of the organ. Consequently, it is improbable that newly formed sympathetic terminals could contain a total TH activity equivalent to that present in the normal organ. Thus, it is reasonable to consider that the carotid sinus nerve itself is responsible for the observed tonic suppression of TH activity in the carotid body. Increase in carotid body TH following deafferentation agrees with the recent finding by Hanbauer and Hellstrom ${ }^{10}$ that carotid body norepinephrine content was increased by $70 \%$ at 5-7 days following section of the carotid sinus nerve. Furthermore, these investigators also showed in another report that recovery of normal carotid body dopamine stores after hypoxiainduced depletion of this catecholamine occurred more rapidly in chronically deafferented carotid bodies than in normally innervated organs ${ }^{12}$. In this regard, it is interesting to note that chronically deafferented cat carotid bodies show an increase in the concentration of dense-cored vesicles in Type I cells, as well as proliferation of reactive Type I cells containing large dense granules ${ }^{23}$.

This work was supported by Public Health Service Grants NS 12636, NS 07938 and DA 00869.

1 Chiocchio, S. R., Biscardi, A. M. and Tramezzani, J. H., Catecholamines in the carotid body of the cat, Nature (Lond.), 212 (1966) 834-835.

2 Dearnaley, D. P., Fillenz, M. and Woods, R. I., The identification of dopamine in the rabbit's carotid body, Proc. roy. Soc. B, 170 (1968) 195-203.

3 De Castro, F., Sur la structure et l'innervation du sinus carotidien de l'homme et des mammiferes. Nouveaux faits sur l'innervation et la fonction du glomus caroticum. Etudes anatomiques et physiologiques, Trab. Lab. Invest. biol. Univ. Madr., 25 (1928) 331-380. 
4 De Kock, L. L., Intraglomerular tissues of the carotid body, Acta anat. (Basel), 21 (1954) 101-116.

5 Fillenz, M., The function of the Type I cell of the carotid body. In M. J. Purves (Ed.), The Peripheral Arterial Chemoreceptors, Cambridge University Press, 1975, pp. 133-142.

6 Gonzalez, C. and Fidone, S., Increased release of $\left[{ }^{3} \mathrm{H}\right]$ dopamine during low $\mathrm{O}_{2}$ stimulation of rabbit carotid body in vitro, Neurosci. Lett., 6 (1977) 95-99.

7 Gonzalez, C., Kwok, Y., Gibb, J. and Fidone, S. J., Effects of hypoxia on tyrosine hydroxylase activity in rat carotid body, $J$. Neurochem., in press.

8 Guidotti, A., Zivkovic, B., Pfeiffer, R. and Costa, E., Involvement of 3',5'-cyclic adenosine monophosphate in the increase of tyrosine hydroxylase activity elicited by cold exposure, Naunyn-Schmiedeberg's Arch. exp. Path. Pharm., 278 (1973) 195-206.

9 Hanbauer, I., Lovenberg, W. and Costa, E., Induction of tyrosine 3-mono-oxygenase in carotid body of rats exposed to hypoxic conditions, Neuropharmacology, 16 (1977) 277-282.

10 Hanbauer, I. and Hellstrom, S., The regulation of dopamine and noradrenaline in the cat carotid body and its modification by denervation and by hypoxia, J. Physiol. (Lond.), 282 (1978) 21-34.

11 Hellstrom, S. and Koslow, S. H., Biogenic amines in carotid body of adult and infant rats - a gas chromatographic-mass spectrometric assay, Acta physiol. scand., 93 (1975) 540-547.

12 Hellstrom, S., Hanbauer, I. and Costa, E., Selective decrease of dopamine content in rat carotid body during exposure to hypoxic conditions, Brain Research, 118 (1976) 352-355.

13 Heymans, C., Bouchaert, J. J. and Dautrebande, L., Sinus carotidien et reflexes respiratoires. II. Influences respiratoires reflexes de l'acidose, de l'alcalose, de l'anhydride carbonique, de l'ion hydrogene et de l'anoxemie. Sinus carotidiens et echanges respiratoires dans les poumons et au dela des poumons, Arch. int. Pharmacodyn., 39 (1930) $400-448$.

14 Kvetnansky, R., Gewirtz, G. P., Weise, V. K. and Kopin, 1. J., Catecholamine synthesizing enzymes in the rat adrenal gland during exposure to cold, Amer. J. Physiol., 220 (1971) 928-931.

15 Lever, J. D. and Boyd, J. D., Osmiophile granules in the glomus cells of the rabbit carotid body, Nature (Lond.), 179 (1957) 1082-1083.

16 Llados, F. and Zapata, P., Effects of dopamine analogues and antagonists on carotid body chemosensors in situ, J. Physiol. (Lond.), 274 (1978) 487-499.

17 Llados, F. and Zapata, P., Effects of adrenoceptor stimulating and blocking agents on carotid body chemosensory inhibition, J. Physiol. (Lond.), 274 (1978) 501-509.

18 McDonald, D. and Mitchell, R. A., The innervation of glomus cells, ganglion cells and blood vessels in the rat carotid body: a quantitative ultrastructural analysis, J. Neurocytol., 4 (1975) $177-230$.

19 Nagatsu, T., Levitt, M. and Udenfriend, S., A rapid and simple radicassay for tyrosine hydroxylase activity, Analyt. Biochem., 9 (1964) 122-126.

20 Sampson, S. R. and Vidruk, E. H., Hyperpolarizing effects of dopamine on chemoreceptor nerve endings from cat and rabbit carotid bodies in vitro, J. Physiol. (Lond.), 268 (1977) 211-221.

21 Thoenen H., Mueller, R. A. and Axelrod, J., Increased tyrosine hydroxylase activity after druginduced alteration of sympathetic transmission, Nature (Lond.), 221 (1969) 1264.

22 Thoenen, H., Mueller, R. A. and Axelrod, J., Trans-synaptic induction of adrenal tyrosine hydroxylase, J. Pharmacol. exp. Ther., 169 (1969) 249-254.

23 Vazquez-Nin, G. H., Costero, I., Echeverria, O. M., Aguilar, R. and Barroso-Moguel, R., Innervation of the carotid body. An experimental quantitative study, Acta anat. (Basel), 102 (1978) $12-28$.

24 Zapata, P., Effects of dopamine on carotid chemo- and baroreceptors in vitro, J. Physiol. (Lond.), 244 (1975) 235-251. 